\title{
Pengaruh Gaya Kepemimpinan, Budaya Organisasi, dan Lingkungan Kerja terhadap Kinerja Karyawan Melalui Motivasi pada PDAM Tirta Mayang Kota Jambi
}

\author{
${ }^{1}$ Muhammad Emil \\ ${ }^{1}$ Magister Manajemen Universitas Batanghari Jambi \\ e-mail: muhammademil74@gmail.com
}

\begin{abstract}
In every organization both government and private, human is an important asset in an effort to achieve the goals that have been determined. Leadership style, organizational culture, work motivation and performance of employees who reside within the organization need to be organized in order to achieve organizational goals. Style leadership, organizational culture and work environment and motivation is one of several factors that can affect employee performance. This study aims to test and analyze these variables on employee performance PDAM Tirta Mayang City Jambi. The study was conducted by using path analysis using SPSS version 22.0 in analyzed data. The test results showed that the hypothesis of leadership style, organizational culture and motivation have positive and significant influence on performance, and testing work environment hypothesis have negative and insignificant effect on employee performance of PDAM Tirta Mayang Jambi City.
\end{abstract}

Keywords: Leadership Style, Organizational Culture, Work Environment, Motivation and Performance

\section{PENDAHULUAN}

Sumberdaya Manusia merupakan asset terpenting dalam suatu organisasi, karena peranannya sebagai subjek pelaksana kebijakan dan kegiatan operasional organisasi. Agar organisasi tetap eksis maka harus berani menghadapi tantangan dan implikasinya, yaitu menghadapi perubahan dan memenangkan persaingan.oleh karena itu diperlukan pengembangan pegawai agar mutu dan kemampuan sumberdaya manusia yang telah ada mampu bersaing dan dapat mengikuti perkembangan zaman, terlebih pada era globalisasi, dimana ilmu pengetahuan dan teknologi diberbagai bidang berkembang dengan sangat pesat

Tabel 1

Sumberdaya manusia PadaPDAM Tirta Mayang Kota Jambi Berdasarkan Pendidikan Formal

\begin{tabular}{rlrr}
\hline No & \multicolumn{1}{c}{ Jenjang Pendidikan } & Jumlah & Persentase \\
\hline 1. & Strata 1 & 63 & 18,16 \\
2. & Diploma III & 31 & 8,93 \\
3. & SLTA/Sederajat & 233 & 67,15 \\
4. & SLTP/Sederajat & 15 & 4,32 \\
\hline
\end{tabular}

Dalam pengelolaan PDAM Tirta Mayang Kota Jambi, kualitas SDM perusahaan ini yang masih relatif rendah karena didominasi karyawan yang berpendidikan setingkat SLTA berjumlah 233 orang,setaradengan67,15\%dari total pegawai PDAM Tirta Mayang Kota Jambi. Dibandingkan yang berpendidikan S1 berjumlah $63(18,16 \%)$ dan D III berjumlah $31(8,93 \%)$. Selain 
disebabkan adanya perbedaan latar belakang pendidikan formal,perbedaantersebuttentunyatidak terlepas dari keterampilan kerja yang ditempa oleh pengalaman kerja yang dimiliki oleh pegawai. Ditambah lagi dengan adanya perbedaan kemampuan teoritis, teknis, dan kemampuan konseptual hingga keterampilan teknis, seperti halnya dalam penggunaan peralatan kerja juga ikut membedakan kualitas SDM pada perusahaan tersebut.(Alhudhori dan Aldino, 2017)

Bahwa PDAM Tirta Mayang Kota Jambi hingga kini baru mampu melayani air bersih kepada sekitar 333.500 jiwa penduduk kota jambi, atau sekitar 58,58\% dari total penduduk kota jambi yang sekitar 569.331 jiwa. Dengan melihat buruknya kondisi manajemen yang dimiliki oleh PDAM Tirta Mayang Kota Jambi, tentunya akan sangat berdampak pada kinerja organisasi dalam mencapai tujuan organisasi yang tertuang kedalam visi organisasi PDAM Tirta Mayang Kota Jambi yaitu "Terwujudnya Perusahaan Pelayanan Air Minum Yang Sehat dan Handal Dengan Sumberdaya Manusia Berkualitas dan Teknologi Yang Cerdas (smart technology)".

Hasil kerja pada PDAM Tirta Mayang Kota Jambi dalam 3 tahun terakhir terus berfluktuasi dengan tren positif (peningkatan) dimana pada tahun 2014 pelanggan PDAM Tirta Mayang Kota Jambi tercatat sebesar 62.883 naik sebesar $1.94 \%$ (tahun 2013 jumlah pelanggan sebesar 61.660) dan pada tahun 2015 PDAM Tirta Mayang Kota Jambi berhasil meningkatkan jumlah pelanggan sebesar 64.847 atau naik sebesar 3\% dari tahun sebelumnya hal ini menunjukan adanya tren yang sangat baik sekali terhadap kinerja karyawan atau prusahaan dan tren ini masih terus meningkat di tahun 2016 PDAM Tirta Mayang Kota Jambi berhasil menambah jumlah pelanggan sebesar 69.379 atau naik sebesar $6,53 \%$ (mengalami kenaikan dua kali lipat dari tahun 2015, yang mengalami peningkatan $3 \%$ ). Secara teoritis sebagaimana diuraikan diatas, kinerja karyawan dapat dipengaruhi oleh beberapa variabel-variabeldiantaranyaadalah gaya kepemimpinan, budaya organisasi, lingkungan kerja, dan motivasi. Oleh karena itu, kinerja karyawan PDAM Tirta Mayang Kota Jambi tentunya juga dapat dikaitkan dengan keempat faktor-faktor tersebut.

\section{Tinjauan Pustaka}

\section{Gaya Kepemimpinan}

Asnawi (2011:1) mengatakan, kepemimpinan adalah kemampuan untuk mempengaruhi, menggerakkan, dan mengarahkan suatu tindakan pada diri seseorang atau sekelompok orang, untuk mencapai tujuan tertentu pada situasi tertentu. Seorang pemimpin sangat dibutuhkan dalam penetapan tujuan organisasi, mengalokasikan Sumberdaya yang dimiliki oleh suatu organisasi, mengkoordinasikan perubahan yang terjadi serta menentukan apa yang harus dilakukan bila terjadi kegagalan.

Gaya kepemimpinan merupakan norma perilaku yang digunakan oleh seseorang pada saat orang tersebut mencoba mempengaruhi perilaku orang lain seperti yang ia lihat (Thoha, 2010:49). Dalam hal ini usaha menyelaraskan persepsi diantara orang yang akan mempengaruhi perilaku dan orang yang perilakunya akan dipengaruhi menjadi amat penting kedudukannya. Dalam menjalankan kepemimpinannya seorang pimpinan biasanya menggunakan gaya kepemimpinan yang dianggap efektif untuk mempengaruhi bawahannya agar memperlihatkan perilaku yang sesuai dengan tujuan organisasi.

\section{Budaya Organisasi}


Djokosantoso (2003:17-18) menyatakan "budaya korporat atau budaya organisasi atau juga dikenal dengan istilah budaya kerja merupakan nilai-nilai dominan yang disebar luaskan didalam organisasi dan diacu sebagai filosofi kerja karyawan".

Sedangkan pengertian budaya organisasi diberikan oleh Pettigrew dalam Sobirin (2009:125), Pattigrew merupakan orang pertama yang secara formal menggunakan istilah budaya organisasi, memberikan pengertian budaya organisasi adalah sistem makna yang diterima secara terbuka dan kolektif, yang berlaku untuk waktu tertentu bagi kelompok tertentu. Karyawan yang sudah memahami keseluruhan nilai-nilai organisasi akan menjadikan nilai-nilai tersebut sebagai suatu kepribadian organisasi. Nilai dan keyakinan tersebut akan diwujudkan menjadi perilaku keseharian mereka dalam bekerja, sehingga akan menjadi kinerja individual.

\section{Lingkungan Kerja}

Ndraha (1997:12) Lingkungan merupakan terjemahan kata environment, yang dinyatakan sebagai keseluruhan yang mengitari, termasuk yang dikitari yaitu manusia yang bersangkutan. Menurut International Encyclopedia of the Social Sciences 1972 (dalam Ndraha, 1997 : 12), lingkungan didefinisikan sebagai "the aggregate of all the external conditions and influences affecting the life and development of an orginism". Dengan demikian lingkungan adalah sesuatu yang mengelilingi manusia, kelompok orang dan mempengaruhinya.

Perkembangan konsep lingkungan kerja dalam hubungan dengan interaksi manusia sampai pada akhirnya melahirkan suatu disiplin ilmu yang disebut Ergonomi. Kata Ergonomi berasal dari bahasa Yunani yaitu Ergos yang berarti bekerja dan nomos yang berarti hukum alam. Menurut Sedarmayanti, (1999 : 1) bahwa Ergonomi adalah ilmu yang mempelajari tentang perkaitan antara orang dengan lingkungan kerjanya. Oleh karena itu ergonomi memanfaatkan informasi mengenai sifat, kemampuan dan keterbatasan manusia untuk merancang suatu sistem kerja sehinggan orang dapat bekerja pada sistem tersebut dengan baik guna mencapai tujuan melalui pekerjaan yang dilakukan dengan efisien, aman, dan nyaman.

\section{Motivasi}

Hersey, et al. dalam Kadarisman (2012:273) menyatakan bahwa "the motivation of people depends on the strength of their motives. Motives are sometimes define as needs, wants, or impulses within the individual". Dengan demikian, membahas motivasi tidak terlepas dari faktor pendorong (motif) mengapa manusia mau berperilaku, berbuat, dan bertindak. Faktor pendorong ini sering kali diidentikkan dengan kebutuhan atau keinginan. Kebutuhan atau keinginan yang dirasakan oleh setiap karyawan pada dasarnya berbeda-beda. Selain itu, kebutuhan atau keinginan yang dirasakan Karyawan sangat kompleks sifatnya. Oleh karyawan, maka pimpinan perlu melakukan survei terhadap setiap bawahannya.

Menurut Robbin dan Judge (2008 : 222-223) motivasi adalah proses yang menjelaskan intensitas, arah, dan ketekunan usaha untuk mencapai suatu tujuan. Tiga elemen utama dalam motivasi adalah intensitas, arah, dan ketekunan. Intensitas berhubungan dengan seberapa giat seseorang berusaha. Intensitas yang tinggi tidak akan menghasilkan prestasi kerja yang memuaskan kecuali upaya tersebut dikaitkan dengan arah yang menguntungkan organisasi. Ketekunan 
merupakan ukuran mengenai beberapa lama seseorang bisa mempertahankan usahanya.

\section{Kinerja}

Sedarmayanti (2007:259) menyatakan, kinerja terjemahan dari "performance", berarti: 1) Perbuatan, pelaksanaan pekerjaan, prestasi kerja, pelaksanaan pekerjaan yang berdaya guna. 2) Pencapaian/prestasi seseorang berkenaan dengan tugas yang diberikan kepadanya. 3) Hasil kerja seorang pekerja, sebuah proses manajemen atau suatu organisasi secara keseluruhan, dimana hasil kerja tersebut harus dapat ditunjukkan buktinya secara kongkrit dan dapat diukur (dibandingkan dengan standar yang telah ditentukan). 4) Kinerja didefinisikan sebagai catatan mengenai outcome yang dihasilkan dari suatu aktivitas tertentu, selama kurun waktu tertentu pula. 5) Hasil kerja yang dapat dicapai oleh seseorang atau sekelompok orang dalam suatu organisasi, sesuai dengan wewenang dan tanggung jawab masing-masing dalam rangka upaya mencapai tujuan organisasi bersangkutan secara legal, tidak melanggar hukum dan sesuai moral maupun etika.

Selanjutnya menurut Gibson, et al. dalam Winnardi (2011) Kinerja (ferformance) merupakan perilaku organisasional yang secara langsung berhubungan dengan produksi barang atau penyampaian jasa. Kinerja seringkali dipikirkan sebagai pencapaian tugas, dimana istilah tugas sendiri berasal dari pemikiran aktivitas yang dibutuhkan oleh pekerja.

Menurut Hasibuan (2005) kinerja adalah Suatu hasil kerja yang dicapai seseorang dalam melaksanakan tugas-tugas yang dibebankan kepadanya didasarkan atas kecakapan, pengalaman dan kesungguhan serta waktu.

\section{Pengaruh Gaya Kepemimpinan, Budaya Organisasi, Lingkungan Kerja, Motivasi Terhadap Kinerja}

Penelitian yang dilakukan oleh Logahan, dkk (2012) tentang analisis pengaruh lingkungan kerja dan pemberian kompensasi terhadap kinerja karyawan CV. MUM Indonesia, menghasilkan kesimpulan bahwa lingkungan kerja tidak berpengaruh positif dan tidak signifikan dengan kinerja, dan motivasi berpengaruh positif dan signifikan terhadap kinerja. Anung (2010) menyatakan, motivasi, kompetensi dan kepemimpinan mempunyai pemgaruh dan siginifikan terhadap kinerja, lingkungan kerja tidak berpengaruh dan tidak signifikan terhadap kinerja dosen negeri yang dipekerjakan pada kopertis wilayah V. Penelitian Winardi, et al (2011) menghasilkan kesimpulan bahwa Budaya organisasi mempunyai pengaruh positif terhadap kinerja, Motivasi mempunyai pengaruh negatif terhadap kinerja dan tidak sifnifikan, Budaya organisasi mempunyai pengaruh negatif terhadap komitmen organisasional dan tidak signifikan, Motivasi mempunyai pengaruh positif terhadap komitmen organisasional dan tidak signifikan, serta Komitmen organisasional mempunyai pengaruh positif terhadap kinerja karyawan dengan tingkat signifikan yang baik pada karyawan dinas pengairan Provinsi Aceh.

Berdasarkan atas kajian teori diatas, maka hipotesis yang diajukan dalam studi ini adalah :

H1 : Gaya kepemimpinan, budaya organisasi, Lingkungan Kerja, motivasi dan kinerja Karyawan PDAM Tirta Mayang Kota Jambi diduga baik.

H2 : Gaya kepemimpinan, budaya organisasi, dan Lingkungan Kerja diduga berpengaruh terhadap motivasi Karyawan PDAM Tirta Mayang Kota Jambi. 
H3 : Gaya kepemimpinan diduga berpengaruh terhadap motivasi Karyawan PDAM Tirta Mayang Kota Jambi

H4 : Budaya organisasi diduga berpengaruh terhadap motivasi Karyawan PDAM Tirta Mayang Kota Jambi

H5 : Lingkungan Kerja diduga berpengaruh terhadap motivasi Karyawan PDAM Tirta Mayang Kota Jambi

H6 : Gaya kepemimpinan, budaya organisasi, dan Lingkungan Kerja diduga berpengaruh terhadap kinerja Karyawan PDAM Tirta Mayang Kota Jambi

H7 : Motivasi Karyawan diduga berpengaruh terhadap kinerja Karyawan PDAM Tirta Mayang Kota Jambi

H8 : Gaya kepemimpinan diduga berpengaruh terhadap kinerja Karyawan PDAM Tirta Mayang Kota Jambi

H9 : Budaya Organisasi diduga berpengaruh terhadap kinerja Karyawan PDAM Tirta Mayang Kota Jambi

H10 : Lingkungan Kerja diduga berpengaruh terhadap kinerja Karyawan PDAM Tirta Mayang Kota Jambi

\section{Model Penelitian}

Pemikiran yang mendasari penelitian ini pada hakekatnya adalah, bahwa gaya kepemimpinan, budaya organisasi, lingkungan kerja, dan motivasi akan berpengaruh pada kinerja karyawan. Seseorang dengan kepemimpinan, budaya organisasi, lingkungan kerja yang baik, dan motivasi yang tinggi akan maka akan semakin tinggi pula kinerjanya. Model penelitian ini dapat digambarkan sebagai berikut :

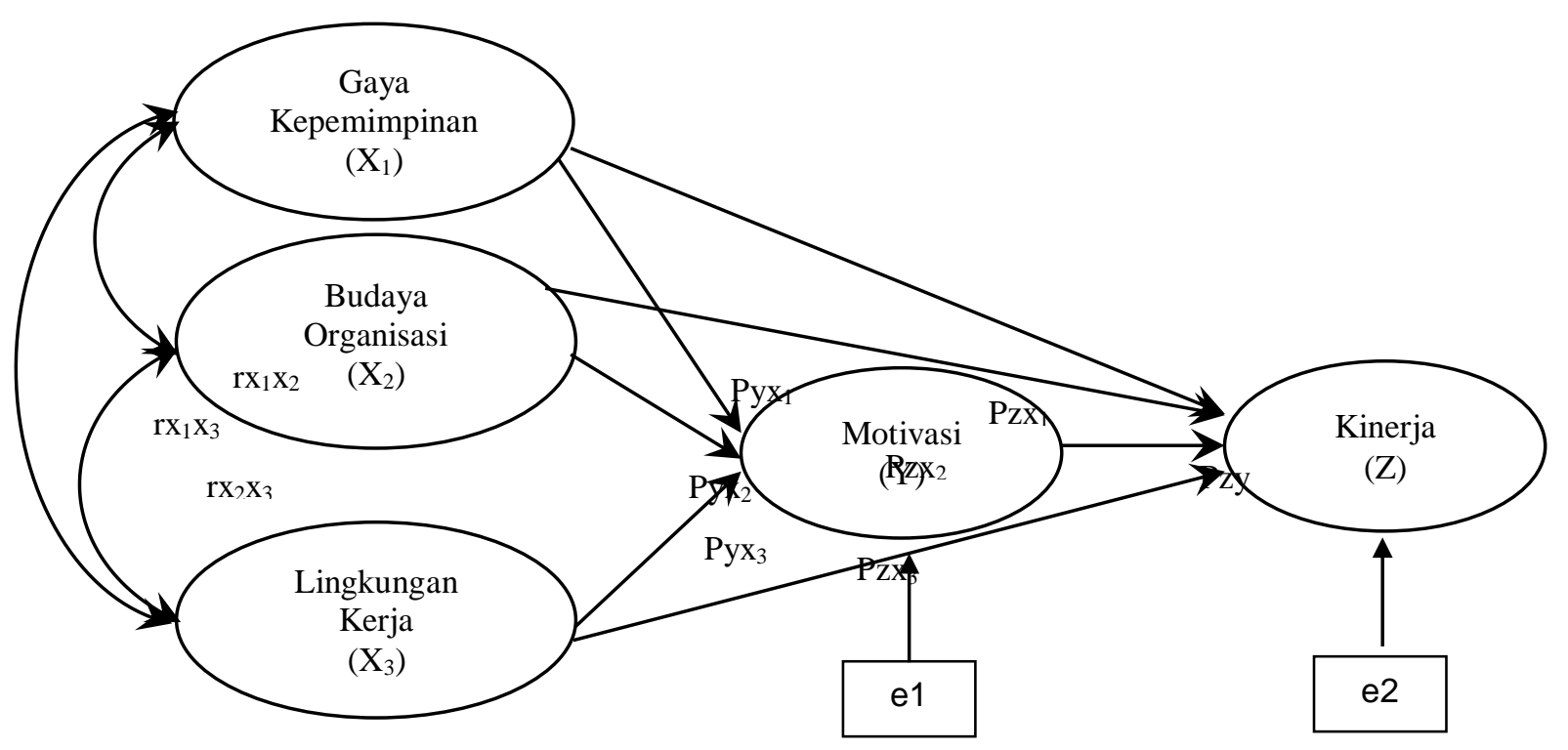

Gambar 1 Model Penelitian 


\section{Metode Sampling dan Pengumpulan Data}

Sampel diambil dari populasi yang berupa karyawan PDAM. Tirta Mayang Kota Jambi yang berjumlah 347 orang. Mengingat jumlah populasi pada PDAM Tirta Mayang Kota Jambi yang terlalu banyak (347 Orang), maka dalam penelitian ini metode yang digunakan adalah metode sampel. Dalam hal ini, data sampel yang akan diambil mengacu pada formulasi menurut Umar (2007:65). Dengan menetapkan angka presisi 10\%, maka diperoleh jumlah sampel minimal, sebesar 78 orang. Penarikan sampel yang digunakan adalah Propotional Random Sampling. Yaitu teknik pengambilan sampel secara acak dengan memperhatikan besarnya jumlah responden pada setiap unit organisasi yang ada pada populasi (Suharsimi, 2006 : 138).

\section{Definisi Operasional dan Pengukuran Variabel}

Variabel-variabel dalam penelitian ini adalah kinerja sebagai variabel dependent, motivasi sebagai variabel mediasi (interverning) serta gaya kepemimpinan, budaya organisasi, dan lingkungan kerja sebagai variabel independent. Variabel-variabel tersebut terlebih dahulu dioperasionalkan agar pengukuran dapat dilakukan.

Kinerja adalah kemampuan dalam melaksanakan tugas dibidangnya masingmasing, kinerja karyawan akan akan dijabarkan kedalam sembilan item pertanyaan dengan menggunakan indikator-indikator yang dikemukan oleh Hasibuan, 2005 : ....indicator-indikator tersebut adalah hasil kerja, kompetensi, perilaku kerja, dan potensi kemampuan serta teknologi.

Motivasi adalah proses yang menjelaskan intensitas, arah, dan ketekunan usaha untuk mencapai tujuan. Motivasi ini akan dijabarkan kedalam delapan item pertanyaan, yang dibuat berdasarkan indicator-indikator yang diambil dari teori motivasi yang di kemukakan oleh Abraham Maslow, yaitu fisiologis, rasa aman, social, penghargaan dan aktualisasi diri.

Gaya kepemimpinan adalah sebagai suatu proses pengarahan dan usaha untuk mempengaruhi aktivitas yang berkaitan dengan tugas dari para kelompok. Pada variabel ini akan dijabarkan kedalam dua belas item pertanyaan, dengan menggunakan indikator yang dikemukakan oleh sunita, yaitu gaya otoriter, gaya pengasuh, gaya birokrasi, gaya partisipatif dan gaya berorientasi tugas.

Budaya organisasi adalah, unit sosial yang sengaja didirikan untuk jangka waktu yang relatif lama, beranggotakan dua orang atau lebih yang bekerja sama dan terkoordinasi, mempunyai pola kerja tertentu yang terstruktur, dan didirikan untuk mencapai tujuan bersama. Pada variabel ini akan dijabarkan kedalam sepuluh item pertanyan yang diambil dari indikator-indikator yang diambil dari hasil riset hofstede et al, yaitu profesionalisme, jarak dari manajemen, percaya pada rekan kerja, keteraturan dan kepercayaan.

Lingkungan kerja adalah, segala sesuatu yang ada disekitar karyawan bekerja yang dapat mempengaruhi dirinya dalam menjalankan tugas-tugasnya. Lingkungan kerja ini akan dijabarkan kedalam sepuluh item pertanyaan, dengan menggunakan indikator yang dikemukakan sedarmayanti (2005). Semua variabel tersebut akan diukur dengan menggunakan skala likert. Masing-masing alternative jawaban akan diberi skor atau nilai 1 untuk jawaban sangat tidak baik, skor 2 untuk jawaban tidak baik, skor 3 untuk jawaban cukup baik, skor 4 untuk jawaban baik, dan skor 5 untuk jawaban sangat baik. 


\section{Pengujian Instrumen Penelitian. Uji Validitas}

Uji validitas dilakukan untuk mengukur tingkat kevalidan atau kesahihan suatu instrument. Secara empiris hasil menunjukan bahwa keseluruhan butir dinyatakan valid dengan menggunakan rujukan, bahwa besaran korelasi tiap butir dalam mengukur variabel diatas 0,227 ( $\mathrm{r}$ tabel).

\section{Uji Reliabilitas}

Uji reliabilitas dilakukan untuk mengukur konsistensi dan stabilitas dari skor (skala pengukuran). Kriteria yang digunakan untuk mengetahui tingkat reliabiltas adalah besarnya nilai cronbach's alpha. Reliabiltas instrument yang semakin tinggi, menunjukkan hasil ukur yang didapatkan semakin terpercaya (reliabel). Hasil empiris dapat dilihat pada tabel 2, yang menunjukkan bahwa keseluruhan item pada reliabel atau konsisten sebagai alat ukur.

Tabel 2

Hasil Pengujian Reliabilitas

\begin{tabular}{clccc}
\hline No. & \multicolumn{1}{c}{ Variabel } & $\begin{array}{c}\text { Koefesien } \\
\text { Reliabilitas }\end{array}$ & $\begin{array}{c}\text { Nilai } \\
\text { rtabel }\end{array}$ & Keterangan \\
\hline 1. & Gaya Kepemimpinan (X1) & 0,862 & 0,227 & Reliabel \\
2. & Budaya Organisasi (X2) & 0,863 & 0,227 & Reliabel \\
3. & Lingkungan Kerja (X3) & 0,647 & 0,227 & Reliabel \\
4. & Motivasi (Y) & 0,818 & 0,227 & Reliabel \\
5. & Kinerja (Z) & 0,799 & 0,227 & Reliabel \\
\hline
\end{tabular}

\section{Hasil Respon Kuesioner dan Karakteristik Responden}

Dalam penelitian ini disebarkan 78 eksemplar kuesioner dengan tingkat response $100 \%$, dan semua kuesioner kembali pada penulis dan kesemuanya dapat diolah. Didapatkan dengan jumlah responden terbanyak pada unit kerja bagian SDM dan Umum yaitu sebanyak 15 orang $(26,92 \%)$ berdasarkan usia, responden tersebar antara kurang dari 30 tahun sampai dengan 51 tahun, dengan yang terbanyak antara usia 31-41 tahun yaitu sebanyak 40 orang (51\%). Berdasarkan jenis kelamin, responden laki-laki sebanyak 49 Orang $(62,8 \%)$ dan 29 Orang perempuan (37,2\%). Berdasarkan pendidikan terakhir ada yang berpendidikan SLTP, SLTA, DIII dan S1, dengan yang terbanyak adalah SLTA yaitu sebanyak 50 orang (64\%). Berdasarkan masa kerja, responden tersebar antara kurang dari 10 tahun sampai dengan lebih 30 tahun kerja, dengan terbanyak mempunyai masa kerja antara 21 sampai dengan 30 tahun yaitu sebanyak 32 orang $(41 \%)$.

\section{Deskripsi Variabel Penelitian}

Hasil rekapitulasi tentang Gaya Kepemimpinan dilingkungan PDAM Tirta Mayang Kota Jambi, menggambarkan bahwa posisi Gaya Kepemimpinan berada pada kategori yang baik. Indikator yang paling tinggi, yaitu Gaya partisipatif, ini menunjukan bahwa gaya partisipatif di PDAM Tirta Mayang ini mendominasi. Gaya ini merupakan gaya yang komunikatif, sebab kontrol atas pemecahan masalah dan pengambilan keputusan seimbang antara pemimpin dan bawahan.

Hasil rekapitulasi tentang variabel budaya organisasi pada PDAM Tirta Mayang Kota Jambi dapat digambarkan, bahwa pada dimensi Profesionalisme dengan kategori baik 82,4 \%. 
Variabel lingkungan kerja pada dimensi Lingkungan non fisik 80,5\% berkategori baik, ini terkait dengan kebutuhan para karyawan, pembagian tugas, profesional dalam bekerja, menjalin hubungan antar pegawai dan terciptanya komunikasi yang baik antar sesama rekan kerja serta pimpinan. tergambarkan dimensi lingkungan non fisik yang menempati rangking pertama, hal ini menunjukan bahwa lingkungan non fisik pada perusahaan ini sudah pada taraf yang baik.

Motivasi pada dimensi Kebutuhan fisiologis pada kategori yang baik 79,6 $\%$, hal ini terkait dengan gaji yang mendukung dan fasiltas lainnya serta tunjangan yang bisa meningkatkan kinerja. tergambarkan dimensi Fisiologis yang menempati rangking pertama, hal ini menunjukan bahwa kebutuhan fisiologis pada perusahaan ini sudah pada taraf yang diharapkan oleh para karyawan. Kinerja karyawan PDAM Tirta Mayang Kota Jambi, bahwa pada dimensi (1) Hasil kerja, 84,1 \% hal ini pada kategori sangat meningkat, ini terkait dengan setiap pekerjaan yang diberikan dapat diselesaikan sesuai dengan waktu yang telah ditentukan.

\section{Pengujian Hipotesis}

Hipotesis dalam penelitian ini dilakukan dengan menggunakan analisis jalur (path analyisis). Adapun hasilnya ditunjukkan pada tabel 2 dan tabel 3.

Tabel 2

Hasil Regresi Variabel Independent Terhadap Interverning (motivasi)

\begin{tabular}{lcccl}
\hline \multicolumn{1}{c}{ Variabel } & Koefisien & t-statistik & Sig. & \multicolumn{1}{c}{ Ket. } \\
\hline Gaya Kepemimpinan & 0,421 & 4,489 & 0,000 & Sig. \\
Budaya Organisasi & 0,434 & 4,556 & 0,000 & Sig. \\
Ling. Kerja & 0,065 & 0,850 & 0,398 & Tidak sig. \\
\hline
\end{tabular}

F Hitung $=37,021$

$\mathrm{R}=0,775$

$\mathrm{R}$ square $=0,600$

Adjusted R square $=0,584$

Pada tabel 2 memperlihatkan, bahwa variabel gaya kepemimpinan dan budaya organisasi berpengaruh secara signifikan terhadap motivasi karyawan pada PDAM Tirta Mayang Kota Jambi, tabel juga memperlihatkan bahwa variabel lingkungan kerja tidak berpengaruh signifikan terhadap motivasi.

Tabel 3

Hasil Regresi Variabel Independent Terhadap Dependent (Kinerja)

\begin{tabular}{lcccc}
\hline \multicolumn{1}{c}{ Variabel } & Koefisien & t-statistik & Sig. & Ket. \\
\hline Gaya Kepemimpinan & 0,349 & 3,832 & 0,000 & Sig. \\
Budaya Organisasi & 0,531 & 5,728 & 0,000 & Sig. \\
Lingkungan Kerja & $-0,041$ & $-0,558$ & 0,579 & Tidak sig. \\
\hline
\end{tabular}

F Hitung $=40,645$

$\mathrm{R}=0,789$

$\mathrm{R}$ square $=0,622$

Adjusted R square $=0,607$

Pada tabel 3 memperlihatkan, bahwa variabel gaya kepemimpinan dan budaya organisasi berpengaruh secara signifikan terhadap kinerja karyawan pada 
PDAM Tirta Mayang Kota Jambi, tabel juga memperlihatkan bahwa variabel lingkungan kerja tidak berpengaruh signifikan terhadap kinerja.

Hipotesis 1 dalam penelitian ini adalah gaya kepemimpinan, budaya organisasi, lingkungan kerja, motivasi dan kinerja Karyawan PDAM Tirta Mayang Kota Jambi diduga baik dapat diterima. untuk lebih jelasnya dapat dilihat pada tabel berikut ini :

Tabel 4

Rentang Skala Variabel-variabel Penelitian

\begin{tabular}{lccc}
\hline \multicolumn{1}{c}{ Variabel } & Nilai & Rentang Skala & Keterangan \\
\hline Gaya Kepemimpinan & 3501 & $3183-3932$ & Baik \\
Budaya Organisasi & 2942 & $2652-3276$ & Baik \\
Lingkungan Kerja & 2976 & $2652-3276$ & Baik \\
Motivasi & 2427 & $2184-2652$ & Baik \\
Kinerja & 2835 & $2388-2950$ & Baik \\
\hline
\end{tabular}

Sumber : Data primer diolah

Hipotesis 2 dalam penelitian ini menyatakan bahwa gaya kepemimpinan diduga berpengaruh terhadap motivasi Karyawan PDAM Tirta Mayang Kota Jambi dapat diterima, karena $\mathrm{p}<0,005$ (Beta $=0,421$, sig. 0,000) dengan $\mathrm{t}-$ statistik 4,489> t tabel 1,669. Dengan demikian dapat disimpulkan bahwa peningkatan gaya kepemimpinan dapat meningkatkan motivasi. Hipotesis 3 dalam penelitian ini menyatakan bahwa budaya organisasi diduga berpengaruh terhadap motivasi Karyawan PDAM Tirta Mayang Kota Jambi dapat diterima. Karena $\mathrm{p}<$ 0,05 (beta $=0,434$, sig. $=0,000$ ) dengan t-statistik 4,556 >t tabel 1,669. Maka dapat disimpulkan bahwa peningkatan budaya organisasi dapat meningkatkan motivasi.

Hipotesis keempat dalam penelitian ini menyatakan bahwa Lingkungan Kerja diduga berpengaruh terhadap motivasi Karyawan PDAM Tirta Mayang Kota Jambi, tidak dapat diterima, karena $\mathrm{p}<0,005$ (beta $=0,398$, sig. 0,065) t statistic $0,850<\mathrm{t}$ tabel 1,669 . Dengan demikian dapat disimpulkan peningkatan atau penurunan kualitas lingkungan kerja tidak akan meningkatkan atau menurunkan motivasi karyawan PDAM. Tirta Mayang Kota Jambi.

Hipotesis 5 dalam penelitian ini menyatakan bahwa gaya kepemimpinan, budaya organisasi, dan Lingkungan Kerja secara bersama-sama diduga berpengaruh terhadap motivasi Karyawan PDAM Tirta Mayang Kota Jambi dapat diterima, $\mathrm{p}<0,005$ (Beta =0,157, sig. 0,000) dan f statistic 37,02 > t tabel 1,669. Berdasarkan hasil tersebut dapat dinyatakan bahwa hipotesis kelima dapat diterima.

Hipotesis 6 dalam penelitian ini menyatakan bahwa motivasi Karyawan diduga berpengaruh terhadap kinerja Karyawan PDAM Tirta Mayang Kota Jambi dapat diterima, karena $\mathrm{p}<0,005$ (Beta $=0,758$, sig. 0,000) dan t statistik 10, 134 $>\mathrm{t}$ tabel 1,669. Berdasarkan hasil uji tersebut, hipotesis 6 dapat diterima.

Hipotesis 7 dalam penelitian ini menyatakan gaya kepemimpinan diduga berpengaruh terhadap kinerja Karyawan PDAM Tirta Mayang Kota Jambi dapat diterima. Karena $\mathrm{p}=0,005$ (Beta =0,349, sig. 0,000) dan t statistik 3,832 > 1,669. Dengan demikian dapat disimpulkan bahwa peningkatan gaya kepemimpinan dapat meningkatkan kinerja. Hipotesis 8 dalam penelitian ini menyatakan budaya Organisasi diduga berpengaruh terhadap kinerja Karyawan PDAM Tirta Mayang Kota Jambi dapat diterima, karena $\mathrm{p}<0,005$ (Beta $=0,532$, sig. 0,000) dan $\mathrm{t}$ 
statistik 5,728 > t tabel1,669. Maka dapat disimpulkan bahwa peningkatan budaya organisasi dapat meningkatkan kinerja.

Hipotesis 9 dalam penelitian ini menyatakan bahwa Lingkungan Kerja diduga berpengaruh terhadap kinerja Karyawan PDAM Tirta Mayang Kota Jambi tidak dapat diterima, karena $\mathrm{p}<0,005$ (Beta $=-0,041$, sig. $-0,558)$ dan $\mathrm{t}$ statistik $0,558<\mathrm{t}$ tabel 1,669. Dengan demikian dapat disimpulkan peningkatan atau penurunan kualitas lingkungan kerja tidak akan meningkatkan atau menurunkan kinerja karyawan PDAM. Tirta Mayang Kota Jambi.

Hipotesis 10 dalam penelitian ini menyatakan bahwa gaya kepemimpinan, budaya organisasi, dan Lingkungan Kerja secara bersama-sama diduga berpengaruh terhadap kinerja Karyawan PDAM Tirta Mayang Kota Jambidapat diterima, berdasarkan $\mathrm{p}<0,005$ (Beta $=0,122$, sig. 0,000) dan f statistik 40,645 > $\mathrm{F}$ tabel 2,73. Berdasarkan hasil tersebut dapat dinyatakan bahwa hipotesis 10 dapat diterima.

\section{SIMPULAN}

Gambaran gaya kepemimpinan, budaya organisasi, lingkungan kerja, motivasi, dan kinerja pada perusahaan PDAM Tirta Mayang Kota Jambi. Berdasarkan hasil analisis data, dapat disimpulkan bahwa semua variabel berada dalam skala baik.

1. Variabel gaya kepemimpinan secara langsung berpengaruh positif terhadap motivasi, untuk itu dapat dikatakan bahwa gaya kepemimpinan yang diterapkan oleh pimpinan organisasi dapat menimbulkan motivasi kerja Karyawan pada perusahaan PDAM Tirta Mayang Kota Jambi. Untuk pengaruh tidak langsung gaya kepemimpinan terhadap kinerja juga berpengaruh positif.

2. Pengaruh langsung budaya organisasi terhadap motivasi baik. Pengaruh tidak langsung dari budaya organisasi terhadap motivasi melalui gaya kepemimpinan berpengaruh positif, dan dengan pengaruh tidak langsung budaya organisasi melalui lingkungan kerja juga positif.

3. Pengaruh Lingkungan Kerja terhadap variabel motivasi positif tapi relatif kecil. Untuk pengaruh tidak langsung variabel Lingkungan Kerja melalui gaya kepemimpinan terhadap motivasi negatif, sedangkan pengaruh tidak langsung Lingkungan Kerja terhadap motivasi melalui budaya organisasi postif, tapi relatif kecil.

4. Pengaruh langsung gaya kepemimpinan, budaya organisasi, Lingkungan Kerja secara bersama-sama terhadap motivasi cukup besar, sedangkan pengaruh tidak langsung cukup besar namun relatif lebih kecil dibandingkan dengan pengaruh langsung.

5. Pengaruh langsung motivasi terhadap kinerja cukup tinggi, keadaan ini menggambarkan bahwa motivasi memberikan pengaruh yang positif terhadap kinerja pada PDAM Tirta Mayang Kota Jambi. Sedangkan pengaruh yang dijelaskan oleh variabel lain relatif lebih kecil.

6. Pengaruh langsung gaya kepemimpinan terhadap kinerja positif. Untuk pengaruh tidak langsung gaya kepemimpinan terhadap kinerja melalui budaya organisasi cukup besar, sedangkan pengaruh gaya kepemimpinan terhadap kinerja melalui Lingkungan Kerja lebih juga positif dan relatif kecil.

7. Pengaruh langsung budaya organisasi terhadap kinerja cukup tinggi. Untuk pengaruh tidak langsung budaya organisasi terhadap kinerja melalui gaya kepemimpinan positif relatif kecil, dan pengaruh tidak langsung budaya organisasi terhadap kinerja melalui Lingkungan Kerja negatif. 
8. Pengaruh langsung Lingkungan Kerja terhadap kinerja negatif. Untuk pengaruh tidak langsung Lingkungan Kerja melalui gaya kepemimpinan negatif, dan untuk pengaruh tidak langsung Lingkungan Kerja terdapat kinerja melalui budaya organisasi juga negatif.

9. Pengaruh langsung gaya kepemimpinan, budaya organisasi, dan Lingkungan Kerja secara bersama-sama terhadap kinerja cukup besar, sedangkan pengaruh tidak langsung cukup besar namun relatif lebih kecil dibandingkan dengan pengaruh langsung. Pengaruh yang dijelaskan oleh variabel lain terhadap variabel kinerja relatif lebih kecil.

10. Pengaruh gaya kepemimpinan terhadap kinerja melalui motivasi positif, pengaruh budaya organiasasi terhadap kinerja melalui motivasi positif dan pengaruh Lingkungan Kerja terhadap kinerja melalui motivasi negatif.

11. Pengaruh gaya kepemimpinan, budaya organisasi, Lingkungan Kerja, dan motivasi secara bersama-sama terhadap kinerja cukup tinggi, sedangkan pengaruh langsung dan pengaruh tidak langsung variabel gaya kepemimpinan, budaya organisasi, Lingkungan Kerja terhadap kinerja tanpa melalui motivasi tinggi namun relatif lebih rendah dibandingkan dengan pengaruh gaya kepemimpinan, budaya organisasi, Lingkungan Kerja dan motivasi secara bersama-sama terhadap kinerja.

\section{DAFTAR PUSTAKA}

Amstrong M., 1994. A Handbook of Human Resources Management, terjemahan, Elex Media Komputindo, Jakarta.

Alhudhori, M., dan Aldino, W., 2017, Pengaruh kepemimpinan dan Disiplin Terhadap Motivasi Kerja Serta Dampaknya pada Kinerja Pegawai Rumah Sakit Umum Bersaudara, Jurnal Manajemen dan Sains, 2(1), 2332

Asnawi, T (2011). Kepemimpinan, Hamada Prima, Jambi

Bahagia, Rahmat (2004). Hubungan Orientasi Kepemimpinan Struktur Inisiasi dan Konsiderasi dengan Kepuasan Kerja Karyawan, Jurnal Ilmiah Manajemen dan Bisnis, Fakultas Ekonomi Universitas Muhammadiyah Sumatera Utara Vol. 4, No. 2 : 133-140

Bukit, Pantun (2012). Model Analisis Kualitatif. Jambi

Djokosantoso, Moeljono (2003). Budaya Korporat dan Keunggulan Korporasi, Elex Media Komputindo, Jakarta.

Fahmi I, (2012). Manajemen Kepemimpinan Teori dan Aflikasi, Alfabeta. Bandung.

Ghozali, Imam, 2005 (cetakan 4, 2011) Metode Persamaan Struktural (Konsep dan Aplikasi) dengan Program Amos. Badan Penerbit Univ. Diponegoro, Semarang.

Ghozali, Imam, (2011). Model Persamaan Struktural Konsep dan Aplikasi Dengan Program Amos 19.0. Semarang.

Griffin W.R (2003. Manajemen, Penerbit Erlangga, Jakarta.

Handoko, T. Hani (2003). Manajemen Personalia dan Sumber Daya Manusia. Liberty, Yogyakarta.

Harun, Cut Hari (2003). Peningkatan Kualitas Sumber Daya Manusia Melalui Pendidikan Merupakan Kunci Keberhasilan Suatu Lembaga di Era Globalisasi dan Otonomi Daerah, Jurnal Pendidikan dan Kebudayaan, Balitbang Diknas, No. 041, Tahun Ke-9, Maret 2003 h. 177. 
Hasibuan, M.S.P. (2003). Manajemen Sumber Daya Manusia, PT. Gunung Agung., Jakarta.

Mangkunegara, AP (2010). Evaluasi Kinerja SDM. Edisi Kelima. Reflika Aditama.Bandung.

Mangkuprawira, Sjafri (2003) Manajemen Sumber Daya Manusia Strategik, Cetakan Kedua, Ghalia Indonesia, Jakarta

Mangkunegara, Anwar Prabu (2005), Evaluasi Kinerja SDM. Refika Aditama.Bandung

Mas'ud, Fuad, 2004. Budaya Organisasi.

Ndraha, Taliziduhu (2002). Pengantar Teori Pengembangan Sumber Daya Manusia, Rineka Cipta, Jakarta.

Ndraha, Taliziduhu, 2003. Budaya Organisasi, Ed 2, Penerbit PT. Rineka Cipta Jakarta,.

Nurjanah (2008). Pengaruh Gaya Kepemimpinan dan Budaya Organisasi Terhadap Komitmen Organisasi Dalam Meningkatkan Kinerja Karyawan(Studi Pada Biro Lingkup Depertemen Pertanian). Tesis Universitas Diponegoro. Semarang

Oie I (2010). Riset Sumber Daya Manusia, Cara Praktis Mengukur Stres, Kepuasan Kerja, Komitmen, Loyalitas, Motivasi Kerja, dan AspekAspek Kerja Karyawan lainnya. Cetakan kelima. PT. Gramedia Pustaka Utama, Jakarta

Pasha, Syarif. "PDAM Tak Mampu, Jambi Sulit Dapat Air Bersih". Suara Pembaruan, 28 Mei 2015. [online] http://sp.beritasatu.com/home/pdamtak-mampu-jambi-sulit-dapat-air-bersih/88352

Prawirosentono, 1999.Kebijakan Kinerja Karyawan.

Priyatno, Duwi (2012). Belajar cepat Olah Data Statistik dengan SPSS. Andi Offset, Yogyakarta

Robbin, S.P dan T.A Judge (2008). Perilaku Organisasi, Edisi 12. Jilid 1 dan 2. Terjemahan. Salemba Empat. Jakarta.

Schermenhorn, Hunt dan Osborn (2003) Manajemen, Edisi Bahasa Indonesia, Penerbit Andi, Yogyakarta.

Sedarmayanti (2002) Restruktisasi dan Pemberdayaan Organisasi Untuk Menghadapi Dinamika Perubahan Lingkungan, Mandar Maju, Bandung , (2007). Manajemen Sumber Daya Manusia: Reformasi Birokrasi dan Manajemen Pegawai Negeri Sipil, PT Refika Aditama, Bandung.

Sobirin A (2009). Budaya Organisasi, UPP STIM YKPM, Yogyakarta

Sopiah (2008). Perilaku Organisasional. ANDI. Yogyakarta

Sudarmadi (2007). Analisis Pengaruh Budaya Organiasi dan Gaya Kepemimpinan

Terhadap Kepuasan Kerja dan Kinerja Karyawan, (Tesis). Semarang.

Sugiono. 2011, Metode Penelitian Administrasi, Alfabeta, Bandung

Susanto, AB (2002). Budaya Perusahaan : Seri Manajemen Dan Persaingan Bisnis.Cetakan Pertama, Elex Media Komputindo, Jakarta.

Suwatno dan Priansa, Donni Juni, (2011), Manajemen SDM dalam Organisasi Publik dan Bisnis, Alfabeta, Bandung.

Syekh, Sayid, (2011), Pengantar Statistik Ekonomi dan Sosial. Gaung Persada (GP), Jakarta

Tampubolon, Biatna D (2007). Analisis Faktor Gaya Kepemimpinan dan Faktor Etos Kerja Terhadap Kinerja Pegawai Pada Organisasi yang Telah Menerapkan SNI 19-9001-2001, Jurnal Standarisasi Vol. 9 No. 3 Tahun 2007:106-115. 
Thoha, Miftah, (2002) Perilaku Kekaryawanan, Rajawali Press, Jakarta. (2010). Kepemimpinan dalam Manajemen, PT. Raja Grafindo Persada, Jakarta.

Umar, Husein (2008). Riset Sumber Daya Manusia Dalam Organisasi, Gramedia Pustaka Utama, Jakarta

Winardi, dkk (2012). Pengaruh Budaya Organisasi dan Motivasi Terhadap Kinerja Karyawan Dengan Komitmen Organisasional Sebgai Variabel Intervening (Studi Pada Karyawan Dinas Pengairan Provinsi Aceh). Jurnal Ilmu. 